\title{
ITGB4 wt Allele
}

National Cancer Institute

\section{Source}

National Cancer Institute. IT GB4 wt Allele. NCI Thesaurus. Code C51176.

Human IT GB4 wild-type allele is located within $17 \mathrm{q} 25$ and is approximately $36 \mathrm{~kb}$ in length. This allele, which encodes integrin beta- 4 protein, is involved in the mediation of cell-matrix and cell-cell adhesion interactions and signal transduction that regulates gene expression and cell growth. 